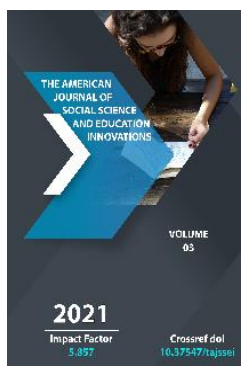

\title{
Moral Upbringing In Educational Sphere
}

\author{
Mukhiddinjon Teshaboev \\ PhD, Fergana Branch Of Tashkent University Of Information Technologies, Republic of \\ Uzbekistan, Fergana City, Uzbekistan
}

Journal Website:

http://theamericanjour

nals.com/index.php/taj

ssei

Copyright: Original content from this work may be used under the terms of the creative commons attributes 4.0 licence.

\section{ABSTRACT}

The article analyzes the issues of great strategic importance, the problems of moral education along with education in society. The article also raises the question of the priority of moral education in the field of education and presents various methods and tools for its solution. The educational possibilities of teaching ethics in the education system and the formation of professional ethics among young people are studied on a scientific basis. In this regard, scientific and practical recommendations are given for improving the mechanisms of teaching ethics in the structure of philosophical disciplines in higher education, taking into account the trends of world scientific development.

\section{KEYWORDS}

Ethics, moral education, ethics, education, educational sphere, globalization, ethical culture, culture of communication, moral decline, moral problems, spiritual life, professional ethics, the system of social sciences, social networks, information and communication networks, teaching professional ethics, rules of etiquette.

\section{INTRODUCTION}

Along with education, the problems of moral education in this area are among the issues of strategic importance for every society. In this sense, this article raises the question of the priority of moral education in the education system and presents various methods and tools for its solution. In the context of globalization, the problems of moral 
education in education are more relevant than ever, and this issue requires a sufficient scientific study. This can be explained by the fact that today's globalized information flow has exceeded the norms of today's technocracy, moral culture has weakened, moral values have depreciated, and in some cases these qualities have been replaced by vices, evil and aggression. This, of course, not only shows how complex the problem is, but also puts on the agenda the creation of scientific mechanisms to find its solutions.

\section{MAIN PART}

Until now, this problem has been studied at different levels and has been deeply studied by Eastern thinkers and Western philosophers. In the east, we can include thinkers like Abu Nasr al-Farabi, Abu Ali ibn Sina, Abu Hamid alGhazali, Yusuf Has Hajib, Alisher Navoi, Hussein Waz Kashifi, Fitrat, Abdullah Avloni. In the West, one can mention such philosophers as Socrates, Plato, Aristotle, Kant, Hegel, Nietzsche, Heinrich David Thoreau. Today, large-scale research is being conducted on these issues. The fact that in our country scientists and philosophers, scientists and researchers from the CIS countries and scientists from prestigious research institutes in Europe and the Pacific region conduct indepth studies of the problems of moral education in education, shows how important this issue is. At the same time, it should be noted that the problems of moral education in education are considered not only as a problem limited to the field of philosophy or ethics, but also in many social, humanitarian and specific, natural sciences. You can also give an example of synergetics, which is a synthesis of many sciences. In general, the main goal of scientists and philosophers of different nationalities, along with all sciences, is to ensure the spiritual purity of human society, to address issues of social development. This shows that the only way to save humanity from degradation is to harmonize education with moral upbringing.

According to the Uzbek educator Abdulla Avloni, the issue of joint moral education in the field of education remains a question of moral education or life or death [1]. World scientists note that the inability to combine moral education with education will lead to moral decline in society. To prevent such catastrophic events, they emphasize the need to prioritize ethical science in the education of generations of all ages around the world. The Russian scientist V. N. Kodin in his article "Foundations of ethical education in our time" writes: "Unfortunately, the universal significance of ethics in teaching all disciplines, one of the most important disciplines for the next generation, is not sufficiently discussed. He writes that the German scientist V.A. Kanke paid great attention to these issues. According to V.A. Kanke, in the 1970 s a synthesis of German cantechism, British utilitarianism and American pragmatism emerged in the field of ethics around the world. Now it has become not only one of the theoretical sciences in the context of metaphysics, but also a program of actions serving real development, and the problems of ethics have become an urgent problem of society [3].

Today, the main question of modern science is: "ls humanity capable of ensuring its own development on an equal footing? » - is an ethical question, and all other disciplines are looking for answers to this ethical question. According to D.E. Moore, in the transition of some sciences from theory to practice, ethics is necessary. Scientists in all fields face ethical challenges when it comes to putting their scientific inventions into practice, and the implications of their inventions are linked to issues of ethics and spirituality. A full 
understanding of the responsibility of the inventor to humanity is an ethical issue [4]. XIX century Western writers Jules Verne in "Hurly-Burly", Herbert Wells in "The Invisible Man", "The Island of Dr. Moreau", and Alexander Belyaev in "Jahangir and "The Amphibian Man" described the devastating consequences of scientific disasters. It follows that talented representatives of various disciplines must have sufficient moral culture to understand that their inventions will ultimately harm humanity. Only then do they begin to understand that they are responsible to humanity, to their conscience.

According to the researchers, the last chapters of textbooks and manuals written for all schools and universities should contain information about whether the knowledge gained in this course meets the moral requirements for repeated application [5]. Because the main goal of educating the younger generation is to educate highly spiritual, versatile, pure, sincere people, while at the same time teaching specialists who know their subject well in various fields. In our opinion, it would be advisable to include the topic of ethics and education in all curricula. It has three interrelated functions: 1 . Providing ethical education for all; 2. Strict moral education; 3. Serves to ensure the moral health of citizens of all ages and social categories. If a roadmap of measures is developed to address these important tasks, it will serve as a necessary guide for instilling in the consciousness of citizens the values of human dignity, honor, and universal morality. It is too early to teach young people etiquette, that is, to start in kindergarten and continue this education for life. In our opinion, according to the proposed roadmap, the rules of etiquette should be legalized, as well as the ban on smoking on buses and in public places. According to the Russian scientist V.N.Kodin, instead of teaching high school students in kindergartens, it is necessary to organize interesting games for morality, respect boys and girls from kindergarten age, give way to adults, never offend them, help them. girls should also be taught etiquette as much as possible, such as respect and gratitude for boys [6]. In this sense, we also need to teach children in kindergarten, school, university, teach them manners, culture of behavior, when each subject is covered. The introduction of one-hour classes on behavioral culture and ethics in secondary schools from the first to the upper grades, as well as an increase in the number of teachers teaching in this area, will also help to strengthen the moral culture of society.

Undifferent from secondary and general education, the educational standards of higher educational institutions should include the teaching of professional ethics as one of the branches of philosophy. At the same time, it is necessary to teach professionals to conscientiously fulfill their duties, medical, pedagogical, entrepreneurial, team leadership ethics, in particular the culture of behavior in these areas. At the same time, it is very important that young people from childhood receive parental education in the family. But if parents fail to raise a child, as in the brochure, and a mistake in this upbringing can make children unhappy for life. Parents should help their children from childhood to choose the path of kindness, honesty, humility, hard work. Unfortunately, many parents here make a big mistake and do not have time to raise their children at home, striving for wealth and a career. Children without parental attachment often grow up to be rude, unhappy, and unable to live independently. Today, in many families, children suffer from parental quarrels. To prevent this from happening, the parent must make sure that 
their child is happy in the future, which should be taken seriously.

Reducing the number of subjects that serve the moral education of the younger generation, especially citizens of all ages, from the budget will have serious consequences for the unethical officials of the country, their interest in unlimited wealth, corruption and the spread of immoral people. We can say that the future of our country literally depends on the moral maturity of young people.

We can call the current period a period of moral maturity or moralism, which is a continuation of the periods of ancient culture, the Renaissance, humanism and rationalism. This idea is consistent with Vernadsky's doctrine of the noosphere. According to this doctrine, in order to preserve the purity of the noosphere, it is necessary to develop technologies for the preservation of nature, to develop civilization in an evolutionary way based on the rational, rational use of natural resources, teaching people a high level of knowledge. spirituality. The science of ethics and spirituality, that is, the philosophy of morality, provides rational guidance for overcoming difficult situations when society is in crisis. This science requires people to be held accountable for their work and duty in order to be honest and well-mannered. Immorality inevitably puts people and society in a spiritual crisis, and moral and human qualities cannot be achieved without moral education. Only when the education system focuses on education will mature people appear.

\section{CONCLUSION}

In conclusion, we can be say that all levels of education need to work together to develop comprehensive curricula and textbooks in the field of universal ethics. In these programs and textbooks, it is advisable to use computer games on the topic of pedagogical ethics as an example of good and bad behavior, proverbs and riddles on topics. It should be noted that the use of exercises that teach the rules of etiquette when organizing various recreational activities in children's, adolescent and youth organizations also gives good results.

\section{REFERENCES}

1. Avloniy A. Selected works. Volume 2, T.: Spirituality, 2006. 304 p.

2. Kodin V. N. Modern ethics as the core of education // Didactics: response to the challenges of pedagogical practice. 2014.474 p.

3. Kanke V.A. Ethics of responsibility: the theory of morality of the future / Viktor Andreevich Kanke. - M.: Logos, 2003.- 351 p.

4. Moore D.E. The Nature of Moral Philosophy: Monograph / George Edward Moore; Per. from English, comp. and note. L.V. Konovalova; Foreword: A.F. Gryaznova and L.V. Konovalova. - M.: Republic, 1999.- 351 p.

5. Ethics: Encyclopedic Dictionary / Ed. R. G. Apresyan, A. A. Guseinova. Moscow: Gardariki, 2001.670 p.

6. Kodin. V.N. Modern ethics as the core of education // Didactics: response to the challenges of pedagogical practice. 2014.474 p.

7. Marifovich, T. M. (2019). Impact of Globalization on Human And Social Culture. International Journal of Scientific Research And Education, 7(4).

8. Karimov, U., Kaxarov, S., Yokubjonov, S., \& Ziyodov, D. (2018). USING NEW INFORMATION TECHNOLOGIES IN DISTANCE LEARNING SYSTEM. In 
The American Journal of Social Science and Education Innovations (ISSN - 2689-100x)

Published: June 30, 2021 | Pages: 180-184

Doi : https://doi.org/10.37547/tajssei/Volumeo3Issue06-30

\begin{tabular}{lcc} 
НОВАЯ & \multicolumn{2}{|c}{ ПРОМЫШЛЕННАЯ } \\
РЕВОЛЮЦИЯ & В & ЗЕРКАЛЕ \\
СОВРЕМЕННОЙ НАУКИ (pp. 9-11).
\end{tabular}

9. Karimov, U., \& Abdurakhmon, A. (2017). INNOVATIVE INFORMATION TECHNOLOGY IN EDUCATION. ФOPYM молодых ученых, (5), 9-12.

10. Teshaboev, M. M. R. (2019). PRINCIPLES OF RELIGIOUS CULTURE AND PRINCIPLES OF CONSEQUENCES OF IMPLEMENTATION. Theoretical \& Applied Science, (10), 669-672. 